DOI: 10.33896/PorJ.2022.1.6

\author{
Olga Łazarowycz \\ Przykarpacki Uniwersytet Narodowy \\ im. Wasyla Stefanyka, Iwano-Frankiwsk (Ukraina) \\ e-mail: olha.lazarovych@pnu.edu.ua \\ ORCID: 0000-0002-4130-2959
}

\title{
JĘZYKOWY OBRAZ DROGI W JEZZYKU POLSKIM I UKRAIŃSKIM
}

Pojęcie językowego obrazu ${ }^{1}$ (JOŚ) świata jest centralnym pojęciem językoznawstwa kognitywnego. W polskim językoznawstwie termin JOŚ został po raz pierwszy wprowadzony przez Walerego Pisarka w Encyklopedii wiedzy o języku polskim [1978]:

\begin{abstract}
Językowy obraz świata, czyli obraz świata odbity w danym języku narodowym, nie odpowiada ściśle rzeczywistemu obrazowi, odkrywanemu przez naukę. Wskutek tego możliwe jest, że między obrazami świata odbitymi w poszczególnych językach narodowych zachodzą znaczne różnice, spowodowane m.in. różnymi warunkami bytowania danych narodów. Szczególnie wyraźnie j. o. ś. odbity w danym języku przejawia się w systemie leksykalnym: najbardziej rozwinięte słownictwo dotyczy $z$ reguły tej sfery zjawisk, która w życiu danej społeczności odgrywa najważniejszą rolę, i odwrotnie, słownictwo, odnoszące się do zjawisk nie mających większego znaczenia charakteryzuje się ubóstwem. Wskutek tego obraz świata odbity w języku przez pryzmat życia społecznego zawiera element subiektywności... Kontakty między narodami, zwłaszcza w ramach jednej wspólnoty kulturalnej, cywilizacyjnej i społeczno-politycznej, pociągające za soba zapożyczenia językowe, sprzyjaja zacieraniu się różnic między obrazami świata odbitymi w językach tych narodów [Urbańczyk (red.) 1992, 146].
\end{abstract}

Następnie termin JOŚ został zaadaptowany przez przedstawicieli lubelskiej szkoły lingwistycznej Jerzego Bartmińskiego i Ryszarda Tokarskiego w artykule Językowy obraz świata a spójność tekstu [1986]. Od tego czasu pojęcie ustabilizowało się w polskim językoznawstwie kręgu kognitywistycznego, czego wyrazem jest m.in. wydanie w roku 1990 tomu pod tytułem Językowy obraz świata, wznowionego w roku 1999 [Grzegorczykowa 2004, 188].

1 Językowy obraz świata jest polskim odpowiednikiem niemieckiego terminu Sprachliches Weltbild, wywodzącego się z XIX-wiecznej koncepcji Wilhelma Humboldta, przyjmującego, że w języku zawarty jest swoisty ogląd świata, wewnętrzna forma, która pośredniczy między językiem a opisywanym światem. Koncepcję tę rozwijało następnie językoznawstwo niemieckie pierwszej połowy XX wieku, przede wszystkim Leo Weisgerber [1927; 1929]. Niezależnie od nich językoznawcy amerykańscy Edward Sapir i Benjamin Lee Whorf, badając języki indiańskie, stwierdzili uderzająca ich odmienność w stosunku do języków indoeuropejskich i wysunęli hipotezę o zależności języka od kultury i warunków życia. 
Teoria JOŚ opiera się na założeniu, że w języku jest zakodowana pewna społecznie uzgodniona wiedza o świecie i że wiedzę tę można zrekonstruować i zwerbalizować w postaci zespołu sądów o ludziach, przedmiotach i zdarzeniach. Wiedza ta jest rezultatem subiektywnej percepcji i konceptualizacji rzeczywistości przez umysł człowieka, ma charakter antropocentryczny, jest zrelatywizowana do języków i kultur [Bartmiński 2012, 229].

Renata Grzegorczykowa rozumie językowy obraz świata jako strukturę pojęciową utrwaloną w systemie danego języka, a więc w jego właściwościach gramatycznych i leksykalnych (znaczeniach wyrazów i ich łączliwości), realizująca się, jak wszystko w języku, za pomoca tekstów (wypowiedzi) [Grzegorczykowa 2004, 41]. Ryszard Tokarski definiuje językowy obraz świata jako zbiór prawidłowości zawartych w zwiąkach gramatycznych i strukturach leksyki, pokazujących różne sposoby widzenia i rozumienia świata [Tokarski 1999].

Można się zgodzić $z$ definicją Jolanty Maćkiewicz, że językowy obraz świata jest tylko częśsia tak rozumianego obrazu świata i to częścią o dość specyficznym statusie. Jest to ta część obrazu świata, która przejawia się w danych językowych [Maćkiewicz 2004, 194]. Termin językowy obraz świata składa się $z$ trzech członów, $z$ których każdy odsyła do innego „wierzchołka” trójkąta semiotycznego: językowy odsyła do wyrazów; obraz - do wyobrażenia (pojęcia, znaczenia); świat - do samej rzeczywistości (choćby to była rzeczywistość tylko wirtualna) [Bartmiński 2012, 238].

Rekonstruując językowy obraz rzeczy i zdarzeń, należy uwzględnić w równym stopniu gramatykę, leksykę, nazwy podstawowe, derywaty słowotwórcze, metafory, frazeologizmy, przysłowia oraz ich tekstowe realizacje, ponieważ u podstaw takiej analizy leży twierdzenie, że dla badań nad JOŚ-em niezwykle istotne sa konceptualizacje motywowane kulturowo, które „zostawiają wyraźne ślady” zarówno w leksyce, jak i w gramatyce każdego języka [Filar, Łozowski 2018, 69].

Koncepcja językowego obrazu świata znajduje współcześnie coraz więcej kontynuatorów wśród językoznawców zarówno w Polsce, jak i na Ukrainie. ${ }^{2}$ Wykorzystanie tej koncepcji w slawistycznych badaniach porównawczych może im nadać nowy wymiar poznawczy, a także otworzyć je na dialog $z$ nowymi kierunkami: lingwistyką antropologicznokulturowa i lingwistyką kognitywna, a w szczególności - z rozwijającą się dynamicznie semantyką międzykulturową [Bartmiński 2012, 229].

2 W językoznawstwie ukraińskim teorię językowego obrazu świata rozwiną Oleksander Potebnia, który podkreślał, że język, którym posługuje się każdy człowiek, ma duży wpływ na formowanie jego myślenia oraz postrzeganie rzeczywistości. Samego terminu JOŚ Oleksander Potebnia nie używał, lecz posługiwał się terminem система изображения (system obrazu). Warto wymienić monografie współczesnych ukraińskich badaczy: [Голубовська 2004; Жайворонок 2007]. 
Punktem wyjścia opisu i analiz porównawczych w tym artykule jest ogólne pojęcie "drogi». Od wieków droga jest bardzo ważnym elementem kultury. Człowiek od dawnych czasów przebywa w ruchu, podróżuje, przesuwa się. Droga jest więc częścia codziennego życia.

Przedmiotem opisu jest mentalny obraz drogi, czyli pojęcie potoczne zabarwione wartościujacco, „koncept”, wyobrażenie utrwalone w potocznym, obiegowym wariancie języka ogólnopolskiego (jak i ogólnoukraińskiego), stojący między wyrażeniem językowym a realnym światem.

W Słowniku frekwencyjnym jezyka polskiego leksem droga ma wysoka pozycję na liście rangowej (136) [Kurcz, Lewicki 1990].

Analizując językowy obraz drogi w dwu zbliżonych do siebie językach, w tym artykule zwrócono uwagę na:

1) werbalizację pojęcia "droga", tj. określenie jednostek leksykalnych (oraz ich etymologii) poprzez ustalenie, jak jest ono reprezentowane w polskich i ukraińskich słownikach jednojęzycznych (co pozwoliło ustalić granice „narzucone temu fragmentowi świata przez określony język" [Maćkiewicz 2004, 197]),

2) całą rodzinę wyrazów, derywaty słowotwórcze od leksemu droga i ich semantykę,

3) frazeologizmy, przysłowia i inne ustabilizowane połączenia wyrazowe $z$ leksemem droga,

4) analizę leksemów w tekstach, w których właśnie realizuje się „rozszerzanie semantyki” badanych leksemów, jak też metafory i metonimie, które odzwierciedlaja sposób percepcji świata.

Warto dodać, że semantyka jest bardzo ważnym polem badawczym, jeśli wziąć pod uwagę prezentację obrazu świata. Chodzi tu nie tylko o referencjalne znaczenie wyrazów, lecz także o całą warstwę konotacji związanych $z$ określonymi wyrazami. Znaczenie wyrazów oraz istniejące między nimi zależności (pola semantyczne, synonimia, powtarzające się przeciwstawienia leksykalne, antonimy uwarunkowane kulturowo) najpełniej i najbardziej wyraziście przekazuja sposób widzenia rzeczywistości przez daną wspólnotę językową.

Badanie przeprowadzono na materiale słowników polskich i ukraińskich, jako źródło posłużyły zbiory przysłów polskich i ukraińskich, a także Narodowy Korpus Języka Polskiego i korpus języka ukraińskiego. Korzystałam także $z$ przeprowadzonych dotychczas badań nad językowym obrazem drogi. Na ten temat powstały niezbyt liczne artykuły, które dotyczyły m.in. analizy nazw drogi [Smyk 2014], profilowania pojęcia "droga" na podstawie idiomatyzmów [Lewicki 1998], konceptu drogi w artystycznym obrazie świata na przykładzie utworów jednego pisarza [Москальчук 2015], językowego obrazu drogi w tekstach poetyckich [Шиеньова 2013; Budrewicz 2002; Wilczewska 2008] czy też były poświęcone porównaniu obrazu drogi w różnych językach - angiel- 
skim i ukraińskim [Мизин 2020], hebrajskim i polskim [Termińska, Szarlej 2015].

Leksemy pol. droga i ukr. dopoza pochodza z języka prasłowiańskiego, a ich współczesna forma powstała - w wypadku języka polskiego w wyniku metatezy bez wzdłużenia samogłoski: pol. droga < ${ }^{*} \operatorname{dorga}(\mathrm{w}$ połączeniu *tort), a w wypadku języka ukraińskiego wskutek pełnogłosu: ukr. dopoza (połączeniu *tort odpowiada pełnogłos torot).

Etymologiczny słownik języka polskiego [Bańkowski 2000, t. 1, 299] podaje etymologie wyrazu droga:

'via' (XIV, dial. dróga), *dorga, og.-słow., ale znaczenie 'via' rozwinęło się tylko w płn.słow.; niejasne, sprawę komplikuje homonimia (kilka różnych *dorg w słow.). Z powodów semantycznych nie można tego sb. wiazać z vb. *dŕg- (p. dziergać, dzierżeć), jak można i trzeba $z$ nim wiązać inne (rzadsze) sb. *dorga 'rodzaj wędki albo sieci rybackiej'; pozostaje uznać za derywat sufiksalny od vb.*der-ti (p. drzeć), określajacy miejsce puste, wąskie a długie, zdatne do przejścia (przejazdu) jako skutek „darcia” roślinności itp., zatem *dhor-g-ã: *dher-[Bańkowski 2000, t. 1, 299].

\section{Wyraz oznacza również:}

'wyżłobienie, wgłębienie; rowek, podłużny ślad wyryty w ziemi, bruzdę wymyta przez wodę, wydeptana; pas ziemi do chodzenia, jazdy' - rzeczownik odczasownikowy od ogólnosłowiańskiego *dŕgati 'ciagnąć, targać, rwać, drzeć' $z$ wymiana ${ }^{*} \hat{r}>{ }^{*}$ or, pierwotnie w znaczeniu 'to, co jest rezultatem cięcia, rwania, darcia - wyżłobienie, bruzda, rowek, podłużny ślad' > wtórnie 'trasa, trakt, utorowany, wydeptany, wyżłobiony przez pojazdy na ziemi' [Słownik etymologiczny języka polskiego online].

Oczywiście nie wszystkie etymologiczne elementy semantyczne zachowały się we współczesnych definicjach słowa droga; należy przyjąć, że:

o ile żywe motywacje słowotwórcze i semantyczne współtworzą obraz świata zawarty w języku i funkcjonujący współcześnie, o tyle w wypadku etymologii można mówić jedynie o stanie minionym, a więc o odbiciu stanu świadomości $z$ okresu tworzenia się języka [Grzegorczykowa 2004, 44].

W definicji słowa gościniec ${ }^{3}$ - 'szeroka droga wiejska o nieulepszonej nawierzchni' [Dubisz (red.) 2003, t. 1, 1055] - (gościniec <*gostin-bč od *gostina, ogólnosł. 'droga główna, publiczna, która się jeździ w gościnę (tzn. w obce strony) albo $z$ niej przyjeżdża $\left\{={ }^{*}\right.$ gostin̋ potb\}' [Bańkowski 2000 , t. 1, 462]) we współczesnej polszczyźnie nie przyją się etymologiczny semantyczny komponent 'jeździć w gościnę albo $z$ niej przyjeżdżać’. Podobnie etymologia wyrazu autostrada - 'kilkupasmowa droga o bezkolizyjnych skrzyżowaniach, przeznaczona do szybkiego ruchu samochodowego' [Dubisz (red.) 2003, t. 1, 159]; - fr. autostrade [1925], wł. autostrada 'droga dla aut' [1922], sztucznie utworzone z: auto + strada 'droga'

3 Wyraz gościniec odnajdujemy w: K. Holly, A. Żółtak, 2001, Słownik wyrazów zapomnianych, czyli słownictwo naszych lektur, Warszawa. 
(z łac. (via) strãta 'droga bita'4 (brukowana) [Bańkowski 2000, t. 1, 20]), nie odzwierciedla współczesnego jego znaczenia.

Leksem droga we współczesnej polszczyźnie ma 5-7 odnotowanych w słownikach znaczeń.

W Uniwersalnym słowniku jezyka polskiego [Dubisz (red.) 2003, 700-702] słowo droga ma 6 znaczeń:

1. 'wydzielony pas ziemi łączący poszczególne miejscowości lub punkty terenu, przystosowany do komunikacji': Do wsi wiodła piaszczysta droga.

2. 'trasa, którą ktoś zamierza lub musi przebyć, odcinek przebywanej trasy, odległość, przestrzeń dzieląca kogoś od określonego celu podróży': Pojechali okrężna droga. Podwieźli go kawałek drogi.

3. 'podróż, wędrówka, przejście, przebywanie jakichś odległości': Odpoczywał po długiej drodze. Od tygodnia był $w$ drodze.

4. utr. a) 'wszelki szlak komunikacyjny, wszelka linia komunikacyjna; trasa': Droga morska, wodna, ladowa. Droga tranzytowa. Otworzyć drogi dla żeglugi; b) 'sposób komunikowania się, przekazywania informacji': Wiadomość otrzymał droga pocztowa.

5. ksiażk. 'sposób postępowania, zachowania się, sposób działania, osiagania czegoś': To jest najlepsza droga do pozyskania jej przyjaźni. Jedyna, właściwa, słuszna droga (postępowania). Wybrać zła droge do osiagniecia czegoś.

6. fiz. 'długość toru przebytego przez poruszający się punkt materialny'.

We współczesnym języku ukraińskim [Русанівський 2013, t. 4, 410-411] przypisuje się leksemowi dopoza 7 znaczeń (tłum. własne):

1. 'pas ziemi, którym jeżdżą i chodzą. Pas, który zostaje jako ślad po czymś'.

2. 'miejsce do przejścia lub przejazdu'.

3. 'przebywanie w ruchu (idąc lub jadąc gdzieś)'.

4. jako przysłówek дорогою (droga); 'w ruchu, w podróży'.

5. 'prawidłowy kierunek dla ruchu kogoś'.

6. przen. 'kierunek działalności, rozwoju'.

7. przen. 'życie człowieka'.

Konotacyjne cechy wyrazu pol. droga, ukr. дopoza, sa wyrażane w zdrobniałych jego formach: w jezyku polskim dróżka: W pobliżu domu jest niewielkie skrzyżowanie ulic i jest dróżka prowadzaca do lasu [Narodowy Korpus Języka Polskiego]; ukr. доріжка, доріжечка, доріженъка: Глухенька доріжка серед хат покрутилася хуторами: Садок пороста травою..: ні стежки, ні доріжечки: Ой куриться доріженька, куриться, куриться [Русанівський 2013, 408].

Należy zaznaczyć, że w znaczeniu wyrazu droga wyodrębnia się cechy definicyjne i konotacyjne. Odróżnienie tych cech jest trudne, ponieważ granice między nimi bywaja słabo wyczuwane przez mówiących i moga się przesuwać w zależności od sytuacji, rodzaju tekstu, posługujących się słowami ludzi. Wśród cech konotacyjnych wydzielić można także cechy asocjacyjne.

4 Droga bita - 'droga o utwardzonej nawierzchni wykonanej ze żwiru lub tłuczonego kamienia i ubitej specjalnym walcem’. 
Leksem droga oznacza 'część przestrzeni', ma 'swoje granice przestrzenne', 'centrum i peryferie', nazywa 'stan powierzchni i materiału', częściej rozważane w kategoriach funkcjonalnych, reprezentuje przestrzeń z punktu widzenia 'wypełniania jej poruszajaccymi się obiektami'. W języku polskim na pierwszy plan wysuwaja się znaczenia: 1) 'pas ziemi łączący poszczególne miejscowości'; 2) 'pas ziemi przystosowany do komunikacji', w języku ukraińskim istotna jest przede wszystkim ta druga funkcja drogi: 'pas ziemi, po którym jeździ się i chodzi'.

Porównawszy definicje słownikowe leksemu droga, można stwierdzić, że w obu językach współtworza je następujacce składniki semantyczne: [1] pas terenu, [2] przystosowany do komunikacji a) ladem, b) woda, c) powietrzem, [3] łączaccy miejscowości, [4] o utwardzonej nawierzchni, [5] wykonanej ze żwiru lub tłuczonego kamienia, [6] przeznaczona do celów a) poruszania się, b) podróży lub wędrówki, c) jakiegoś postępowania, [7] szukanie drogi a) sposobu porozumienia się, b) dotarcia do kogoś, [8] wybór własnego indywidualnego rozwiąania (chodzić swoimi drogami), [9] wejście/zejście na dobra/złą drogę. Oczywiste jest, że tę listę można rozwinąć, analizując znaczenie „konkretnej drogi”, ważną rolę odgrywa kontekst.

$\mathrm{Na}$ oznaczanie różnych rodzajów dróg w języku polskim odnajdujemy takie leksemy jak: autostrada - 'kilkupasmowa droga o bezkolizyjnych skrzyżowaniach, przeznaczona do szybkiego ruchu samochodowego' [Dubisz (red.) 2003, t. 1, 159]; szosa - 'droga o twardej nawierzchni przeznaczona dla pojazdów' [Dubisz (red.) 2003, t. 3, 1533]; magistrala - 'główny szlak komunikacyjny lub transportowy' [Dubisz (red.) 2003, t. 2, 527]; ścieżka - 'wąski pas ziemi wydeptany przez ludzi lub zwierzęta albo specjalnie przygotowany dla pieszych'; obwodnica - 'droga biegnaca dookoła miasta lub śródmieścia, której zadaniem jest odciążenie ruchu w mieście i ułatwienie przejazdu' [Dubisz (red.) 2003, t. 2, 1097] i in.

W Słowniku wyrazów bliskoznacznych [Ludwiczak, Piskadłowa, Tarka-Huczek 2004, 48-49] leksem droga ma około 36 synonimów:

droga - arteria: Arteria wielkomiejska; magistrala: Nowoczesna magistrala; linia komunikacyjna: Międzynarodowa linia komunikacyjna; trakt: Szeroki trakt; gościniec: Błotnisty wyboisty gościniec; szosa: Szosa bita, wyasfaltowana-pierwszej klasy; autostrada: Nowoczesna autostrada; obwodnica: obwodnica omijajaca miasto; pas: Pas szybkiego ruchu; nitka: Nitka autostrady; ulica: Główna, boczna, gwarna, ludna ulica; uliczka: Staromiejska uliczka; zaułek: Ciasny zaułek; ścieżka: Przydrożna, leśna, ogrodowa ścieżka; dróżka, drożyna: Polna drożyna; steczka (gwar); perć: Górska perć; miedza: Iść miedza; przydroże, aleja: Aleja parkowa, lipowa; bulwar: Nadrzeczny bulwar, planty: Planty krakowskie; promenada: Nadmorska promenada; korso: Szerokie zadrzewione korso; esplanada: Reprezentacyjna esplanada; deptak: Uzdrowiskowy deptak; pasaż: Pasaż śródmiejski; ciag: Ciag handlowy; chodnik: Wyboisty chodnik; trotuar (dawn.): Elegancki trotuar, pobocze: Pobocze dla rowerzystów; jezdnia: Jezdnia asfaltowa, dla ruchu kołowego; tor: Tor kolejowy; przecznica: Ruchliwa przecznica; bocznica: Bocznica kolejowa; objazd: Objazd kolejowy.

Wielki słownik wyrazów bliskoznacznych [Latusek, Pilarski 2012, 122] wyróżnia pewne grupy nazw odnoszone do poszczególnych zakresów 
znaczeniowych drogi, korespondujacych ze składnikami definicji słownikowej tego leksemu. Taka formuła pozwala zestawić dokładne synonimy, które maja jak najwięcej wspólnych składników semantycznych:

\section{Droga:}

- (droga krajowa) ulica, szosa, autostrada; dróżka, drożyna, ścieżka, gościniec;

- (droga handlowa) trasa, szlak, trakt, tor, linia;

- (droga do przebycia) odległość, odcinek, dystans;

- (być w drodze) podróż, wędrówka, jazda; wędrowanie, podróżowanie;

- (załatwić coś drogą dyplomatyczna) sposób, postępowanie, metoda.

Oprócz tego do każdego $z$ wymienionych wyżej wyrazów możemy znaleźć w tym słowniku ciagi synonimiczne. Każdy ciagg synonimiczny zawiera wyrazy, które maja pewne wspólne składniki semantyczne [Latusek, Pilarski 2012, 122]:

autostrada - trasa szybkiego ruchu, arteria, droga główna, prosta droga; obwodnica, magistrala, linia komunikacyjna, szosa; ulica, aleja, bulwar, promenada; trakt, gościniec, korso, esplanada; jezdnia, twarda nawierzchnia, asfalt, beton. Możemy tu wyodrębnić pary słów: autostrada - trasa szybkiego ruchu; autostrada-obwodnica; autostrada-ulica; autostrada - trakt; autostrada-jezdnia;

szlak - (szlak turystyczny) - droga, trasa, trakt, linia komunikacyjna;

ścieżka - dróżka, ścieżyna, drożyna, dukt, miedza; ścieżyna, dróżka, drożyna, steczka, dukt, miedza; uliczka, przecznica, bocznica, droga podporzadkowana, objazd, obejście, dojazd, dojście, podjazd; pasaż, ciag spacerowy, planty; trotuar, chodnik, pobocze; zautek, labirynt, meandry, bezdroża, wertepy, manowce, przydroże; przejście, tunel, przełaz, przesmyk; przejście dla pieszych, pasy, zebra; skrzyżowanie, rondo, krzyżówka, rozdroże, rozstaje, rozstajne drogi, rozwidlenie, rozgałęzienie, rozjazd; bruk, brukowiec, żużel, szuter, piach, piasek, nieutwardzona nawierzchnia; chodnik - (chodnik w parku) trotuar, ścieżka, dukt, deptak, aleja, alejka, promenada.

Każdy ciag synonimiczny ma swoje cechy inherentne, takie jak np. budowa, kształt, forma, materiał, i cechy relacyjne, czyli wynikające $z$ relacji danego obiektu do człowieka (przeznaczenie, możliwość wykorzystania, funkcja itp.).

W języku ukraińskim wyraz dopoza (w pierwszym i drugim znaczeniu) tworzy związki synonimiczne $z$ takimi wyrazami jak nymb, uлrяx, mpaca, тракт, магістраль, шосе, стежка, стежина, poetyckie mpona, potoczne гостинеuь, rzadkie манівиі (albo манівеuь), a także wyrazy motywowane forma wewnętrzna - nутівець, nростеuь, кам'янка [Бурячок 1999]. Synonimy tworza połączenia tautologiczne uияx - дорогa, nymь - дорога, metaforyczne путь - доріженька [Москальчук 2015].

W języku polskim wyraz droga może przeciwstawiać się innym wyrazom: droga - bezdroże, droga - lot, droga - postój, droga bez wyjścia, droga do nikad - celowość, droga główna - droga podporzadkowana, droga krzyżowa - idylla, Droga Mleczna - kula ziemska, droga postępowania - koncept, droga naturalna - nienaturalnie [Dąbrówka 2001, 97]. W języku ukraińskim antonimem wyrazu дорога jest бездоріжжжя (pol. bezdroże, bezdroża). 
Antonimy nazywaja „coś przeciwnego”, ale są też sobie bardzo bliskie znaczeniowo - odnosza się do tego samego elementu rzeczywistości opisywanej słowami [Dąbrówka 2001, 7]. Synonimy i antonimy nie informują o tym, co znaczą słowa języka polskiego, ale o tym, jakie są relacje między znaczeniami słów: co mają ze sobą wspólnego i czym się różnią.

Ważnym składnikiem językowego obrazu świata są konotacje semantyczne. Sa to:

cechy (oceny, emocje) kojarzone przez ogół użytkowników języka (lub przez niektóre środowiska, a nawet jednostki) $z$ desygnatami nazw, utrwalone $w$ pewnych faktach językowych (metaforach, derywatach, frazeologizmach) [Grzegorczykowa 2004, 44].

Analiza frazeologizmów opartych na różnych znaczeniach leksemu droga, a także cech, wynikających $z$ łączliwości leksykalnej i frazeologicznej tego wyrazu, pozwala zrekonstruować wyobrażenia zwiąane $z$ pojęciem "drogi». Integralny sem drogi - 'wydzielony pas terenu przystosowany do komunikacji' - rzadko jest składnikiem semantycznym frazeologizmów. Można znaleźć kilka tego typu przykładów, takich jak frazeologizm droga wolna ${ }^{5}$ - używana w komunikacji formuła oznaczająca, że można przejechać, przejść, czy odnotowane w Słowniku peryfraz, czyli wyrazów omownych wyrażenie droga żelazna - 'kolej lub linia kolejowa' - oznaczone jako przestarzałe [Bańko 2009, 50]:

Po przyjeździe na podrzędną stacyjkę drogi żelaznej dwaj przyjaciele zastali oczekującą na nich czwórkę koni zaprzężoną do małego a wysokiego pojazdu na dwie osoby (...) [Stefan Żeromski, Przedwiośnie].

W języku ukraińskim potoczne залізна дорога ma również synonim залізниия - 'droga $z$ linią kolejowa przeznaczona do przesuwania się pociagów': I залізниию через тайгу прокладуть... [Словник украӥнської мови online]. Częściowo pierwsze znaczenie wyrazu droga w języku ukraińskim zawiera frazeologizm обминати (обходити) десятою дорогою 'nie spotykać się $z$ kimś'.

Wyraz droga nie jest wyłącznie nazwą wyróżnionego fragmentu świata, ale także przedmiotu ukształtowanego wyobrażeniowo i symbolicznie, $z$ którym wiaże się cała sfera emocjonalna. Językowy obraz drogi nie odzwierciedla całkowicie rzeczywistości. Słowa nie pokazuja rzeczy dosłownie, lecz jedynie mentalnie. Wyraz droga może odnosić się do przestrzeni, ale także w niektórych wypadkach może być miara czasu.

W kształtowaniu metafory życie to droga istotna funkcję pełni pojęcie czasu. Czas, obok przestrzeni, jest podstawowa cechą charakteryzujacca konkretna, ziemską rzeczywistość. Od tych dwóch czynników zależne jest życie każdego organizmu. Poświadcza to m.in. teoria względności,

5 Tu i dalej frazeologizmy polskie podaję za: S. Skorupka, 1999, Słownik frazeologiczny języka polskiego, t. 1-2, Warszawa. 
traktująca o tym, że wszystkie zjawiska fizyczne zachodzą w tzw. czasoprzestrzeni, czyli właśnie w przestrzeni i czasie [Wilczewska 2008, 223]. Anna Pajdzińska podkreśla, że:

wśród tego, co utrwalone społecznie, istotne miejsce zajmuja jednostki frazeologiczne (...), że frazeologizmy nazywaja przede wszystkim te fragmenty rzeczywistości, które sa zwiąane $z$ człowiekiem [Pajdzińska 2004, 83].

Droga, ukr. дорога (także стежка, стежина, путь, илях) - to bardzo ważne komponenty frazeotwórcze w płaszczyźnie „człowiek - przestrzeń - czas - działanie”, które łączą obraz człowieka z dającymi się zauważyć i niedostrzegalnymi dziedzinami życia. W specyficznej frazie droga życiowa, ukr. житmєва дорога, ${ }^{6}$ wyraz droga jest synonimem wyrażenia odcinek czasu - 'ludzkie życie, los, bytowanie', stąd pol. utorowana droga, ukr. вторована (утерта, утоптана, бита) дорога, стежка; вторований (утертий, утоптаний, битий) илях; проторована дорога - 'lekki, zwykły, sprawdzony tryb życia'; na nowej drodze $\dot{z} y c i a$ - 'w nowym okresie życia' (zwykle o okresie po zawarciu małżeństwa), mówi się również dziecko $w$ drodze, ukr. дитина в дорозі, kiedy rodzice oczekuja urodzenia dziecka. Parafrazie 'życie pełne trudów i cierpień, określenie życia pełnego trosk, udręczeń, problemów, trudności' odpowiada frazeologizm droga krzyżowa, ukr. хресна дорога.

Trzeba powiedzieć, że w kulturach słowiańskich komponent semantyczny leksemu droga odnosi się również do przedśmiertnego odcinka życia i oznacza 'koniec życia', 'zbliżenie ze śmiercia': pójść $w$ droge ku wieczności, zakończyć droge - 'umrzeć'. W ukraińskiej kulturze słowo дорога jest również przywoływane często, kiedy mówi się o śmierci: ukr. [бути] на Божій (останній) дорозі, ${ }^{7}$ збиратися в дорогу, уже на дорозі, іти в дорогу додому; пора збиратися в дорогу; уже в дорозі; в дорозі до Бога - 'czas przed śmiercią' albo 'czas śmierci'; проводжати (провести) в останню дорогу - 'pożegnać na pogrzebie', pol. odprowadzić (kogoś) $w$ ostatnia droge. Śmierć w ludowej kulturze słowiańskiej jest przedstawiana jako podróż do innego świata. W języku ukraińskim wyraz droga może być zastapiony wyrazem nymъ: ten, kto umiera'ŭde (відnpaвляється) y далекy nymъ', pol. wybiera sie $w$ daleka droge. Czasem komponent konceptualny дорога łączy się z przymiotnikami божий, вічний, далекий, останній, задній.

Postępowanie człowieka może być oceniane pozytywnie bądź negatywnie, czego ilustracja sa związki frazeologiczne: być na dobrej drodze, ukr. виходити на вірну дорогу - 'postępować właściwie, uczciwie'; cho-

6 Tu i dalej frazeologizmy ukraińskie podaję za: В. Винник (ред.) 2003, Словник фразеологізмів украӥнської мови, Київ; Фразеологія сучасної української мови, http: / / schoollib.com.ua/ukr_lang/1/54.html

7 W ukraińskiej tradycji narodowej wyrażenie остання дорога bywa czasem używane jako eufemizm wyrazu cмepmъ. 
dzić (iść) prosta droga - ukr. ǔmu прямою дорогою (стежкою) - ‘żус́ uczciwie, być otwartym, szczerym, prostolinijnym'; być na najlepszej drodze (do czegoś) - 'znajdować się blisko celu, konsekwentnie się rozwijać'; w języku ukraińskim вибиватися (вибитися) на [широку] дорогу; виходити на вірну дорогу - 'wybrać prawidłowy kierunek, drogę w życiu, swoje miejsce w społeczeństwie'; наставити (спрямувати) на [добру(вірну)] путь (илях, стежкк) кого - 'skierować kogoś na właściwy szlak'; iść kręta droga, chodzić krętymi drogami, ukr. cmaвamu (ступати) / стати (ступити) на слизький шлях (слизьку дорогу); збиватися з дороги; збочувати з дороги (зі шияяху); збитися з дороги на манівиі; збиватися з путi - 'postępować nieuczciwie, żyć niezgodnie z normami etycznymi'; zejść, zboczyć z prostej drogi, ukr. зійmu з рівної дорогu - 'przestać żyć, postępować dobrze, uczciwie'; sprowadzić kogoś na dobra / zła droge, ukr. збивати (збити) когось з дороги; збивати з nymmr - 'nakłonić kogoś (często własnym przykładem) do właściwego (niewłaściwego) postępowania'; wchodzić komuś $w$ drogę; stawać komuś na drodze, ukr. застуnamu (заступитu) дорогу [y житmя] 'mieszać się w czyjeś sprawy, przeszkadzać komuś w realizacji jakiegoś celu' czy odwrotnie - zejść komuś z drogi, ukr. зiŭmu з дороzu - 'wycofać się $z$ czegoś, aby nie przeszkadzać'; (nie) wchodzić sobie $w$ droge - '(nie) przeszkadzać sobie nawzajem, (nie) utrudniać działania; nie tędy droga - 'niewłaściwy sposób postępowania'; дорога (стежка) терном (ожиною, кропивою itd.); шилях заріс терном, тернами - 'coś zapomnieć na zawsze'.

Drogę osiagnięcia celów oraz poszukiwanie sposobu rozwiązania problemu ilustruja frazeologizmy: otwierać albo torować droge do czegoś, ukr. пробивати (пробити) собі дорогу - 'ułatwiać sobie dostęp do czegoś, realizację czegoś; umożliwić coś, pomagać w osiagnięciu czegoś’; być na drodze do czegoś - 'mieć możliwość osiagnięcia czegoś; dobrze rozpocząć'; ustępować, usuwać się, schodzić komuś z drogi - 'nie przeszkadzać, ułatwiać komuś sytuację, osiagnięcie celu przez usunięcie się'; zatrzymać się, wstrzymać się $w$ pót drogi, ukr. затриматися на півдорозі - 'nie zrealizować zamiaru, nie wykonać czegoś; szukać drogi, znaleźć droge do kogoś, ukr. знайmu дорогу до когось - 'szukać sposobu, znaleźć sposób dotarcia, dostępu do kogoś, porozumienia się z kimś'; 'możliwość osiagnięcia czegoś, dostania się do czegoś' ilustruje frazeologizm otwierać albo torować droge do czegoś, ukr. відкривається (відкрився, відкривати) шиях (дорогу) - 'ułatwiać dostęp do czegoś, realizację czegoś; umożliwić coś, pomagać w osiagnięciu czegoś'; droga polubowna - 'załatwienie sprawy spornej w sposób kompromisowy, przez porozumienie się stron'; droga prawna - 'ustalony przez prawo sposób prowadzenia spraw sądowych lub urzędowych'; droga sądowa - 'działanie sądów, od niższych do wyższych instancji, zależnie od sprawy i atrybucji sądów'.

Jeżeli ktoś przestaje utrzymywać $z$ kimś kontakt, mieć jednakowe poglądy lub wspólne interesy, to mówimy, że (czyjeś) drogi się rozchodza, 
ukr. дороги розходяться / розійилися. Jeżeli ktoś nie postępuje jak inni, kieruje się własnymi zasadami, to mówimy, że on chodzi własnymi drogami, czyli jest indywidualistą. Z kolei ktoś, kto szuka łatwiejszego, prostszego sposobu osiągnięcia jakiegoś celu, zdobycia czegoś, ten chodzi droga na skróty. Droga bez powrotu oznacza 'decyzje, których nie można już cofnać, zmienić'; 'dużą odległość' oddaje frazeologizm szmat, kawał, świat drogi. Ponadto w języku polskim 'zmierzać dłuższa droga do celu podróży' to inaczej nadrabiać drogi, nakładać drogi, natomiast 'zabranie komuś czegoś gwałtem, bezprawnie' można nazwać rozbojem na równej drodze, ukr. шлях найменшого опору, pol. linia najmniejszego oporu 'wybierać lekki sposób osiagnięcia czegoś lub omijanie przeszkód'.

Okrzyk droga wolna! wyraża 'obojętność w stosunku do powziętej przez kogoś decyzji (np. decyzji odejścia, odjazdu)', Droga Mleczna, ukr. Молочний шиях - to 'postrzępiona smuga mglistego światła na niebie, utworzona $z$ miliardów gwiazd galaktyki, do której należy też nasz Układ Słoneczny'.

Nie znaleźliśmy jednak w języku polskim odpowiedników ukraińskich frazeologizmów забувати (забути) дорогу (стежку) куди - 'rzadko kogoś odwiedzać'; не заростають / не заростуть стежки - 'nie zароminać kogoś, odwiedzać kogoś często'; зав'язати дорогу комy - 'stawać na drodze, przeszkadzać ruchowi'; статu / стояти поперек дороги 'przeszkadzać'; стовповий (верстовий) шиях, стовпова (верстова) дорога - 'główny kierunek ruchu albo w rozwoju czegoś'; шлях заказаний - 'ktoś pozbawiony możliwości, dostępu do czegoś'; mydu ŭ дорогa, pejoratywne скатертю дорога ${ }^{8}$ - 'podkreśla się zgodę $z$ tym, że ktoś zasługuje na taki los i nie należy go żałować; обминати (обходити) десятою дорогою - 'nie spotykać się z kimś, mijać go'; з широкої дороги (бандит, розбійник) - 'zacięty bandyta'; дороги не доторкатися (не доторкуваmися) - 'biec bardzo szybko'; як той горох при дорозі [хто не йде, той скубне] - 'ciężki los, ciężkie życie'; при битій дорозі- 'w miejscu skupienia ludzi, dużego ruchu'. Stąd przysłowie Коли на mе пiðе, mо й серед битого шияху поламаєися. Nie ma odpowiedników w języku ukraińskim do takich polskich frazeologizmów: droga cnoty - 'postępowanie zgodne z zasadami etycznymi', nie ma złej drogi zemście na wrogi.

W ukraińskiej ludowej tradycji droga jest niejako zewnętrznym locus w przeciwstawieniu do czegoś wewnętrznego (domu, podwórka), czyli granica między „swoim” a „obcym”. Antonimiczne frazemy на дорозі не валяеться 'о czymś cennym' oraz хоч на дорогу викинь ‘о czymś niepotrzebnym' wiążą się $z$ tym, że to właśnie na drogę, poza granice własnego domu, wyrzucano niepotrzebne rzeczy.

8 Semantyka wyjściowa tego frazeologizmu była pozytywna: jako życzenie prostej szczęśliwej drogi. Antonimiczne znaczenie pojawiło się później. Zob. Фpaзеологія сучасної української мови, http://schoollib.com.ua/ukr_lang/1/54. html 
Wyrażenia $z$ wyrazem dopoza wykorzystuje się na oznaczanie wszystkich faz oraz działań, poczatku albo poszukiwania drogi, przygotowywania się w drogę: ukr. збиратися (лагодитися) в дорогу, готуватися в дорогу, виряджати в дорогу, виглядати [з дороги], спитати, показувати, розпитувати, шукати, вказати дорогу, знати, забути дорогу тощо [Фразеологія сучасної української мови]; pol. zbierać się $w$ drogę, pytać o droge, pokazywać droge, szukać drogi, zapomnieć drogę.

System wartości wspólnoty językowej znajduje odzwierciedlenie $\mathrm{w}$ językowych formułach grzecznościowych. Leksem droga pojawia się w dwóch: szczęśliwej drogi / podróży! i szerokiej drogi! [Lewicki 1998, 281]; ukr. шасливої дороги.

Przysłowia, sentencje, aforyzmy zawsze były bardzo ważną częścia językowego obrazu świata. Zdroworozsadkowe postrzeganie świata skutkuje $z$ jednej strony racjonalnością w logicznym porządkowaniu życia, $z$ drugiej zaś naiwna jego interpretacją [Skorupska-Raczyńska 2013, 62]. Analiza konceptu drogi pozwala dostrzec jego przejście $z$ dziedziny natury do sfery mentalnej. Porównując przysłowia w obydwu językach słowiańskich, można zauważyć, co oznacza pojęcie "drogi» dla Polaków i dla Ukraińców, czym jest ono w różnych sytuacjach ich codziennego życia. Zarówno frazeologizmy, jak i przysłowia ${ }^{9}$ [Kłosińska 2004], sentencje i wyrażenia prezentuja główne dla obu kultur wyobrażenie mentalne 'życie to droga', 'prosta droga' i 'droga na skróty', 'cele podróży', 'nieprzewidywalność wydarzeń podczas podróży'. Ludzie zawsze wierzyli, że „w drodze” pomaga Bóg, w zbiorowej wyobraźni utrwalił się obraz trudu i niebezpieczeństw towarzyszących drodze (życiu), co podkreślają paremie: Życie jest droga, nigdy nie wiadomo, kiedy zmieni kierunek; Kto drogi prostuje, ten $w$ domu nie nocuje / Хто навпростеuь ходить - той дома не ночує; Choć droga niedaleka, nie dojdziesz, jeśli do celu nie zmierzasz; Dobrymi chęciami droga do piekła jest wybrukowana / Благими намірами дорога до пекла вимошена; Ubogiemu zawsze wiatr w осzy, a droga pod górkę; Gdzie przykra droga, zdaj się na Boga; Bez Boga i z górki przykra droga; Chleb $w$ drodze nie ciązy; Ładny kwiatek krótko przy drodze stoi; Stary $i$ mały jedna droga chodza; na miejsce kobiety w dawnym domu i jej obowiazki wskazuje przysłowie Babska droga od pieca do proga.

W języku polskim utrwaliły się autorskie wyrażenia i sentencje, w których droga jest centralnym obrazem, $z$ których można było czerpać mądrość, radę, sposób rozwiazywania problemów czy postępowania. Dobrze obrazuja to przykłady: Kto nie trzyma sie drogi pośredniej, ten nigdy nie idzie bezpieczna ścieżka ${ }^{10}$ [Seneka Młodszy]; Droga do prawdy wy-

9 To przysłowie i następne pochodzą ze zbiorów przysłów Przysłowia polskie, http://przyslowia-polskie.pl/slowo/droga; też [Kłosińska 2004].

10 Wyrażenia i sentencje sa cytowane za: Przysłowia i cytaty na każda okazję, złote myśli, sentencje i wyrażenia, https:/ / cytaty24.pl/cytaty/Droga/Aforyzmy,Sentencje $/ \mathrm{k} / 19$ ?pagec $=1$ 
brukowana jest paradoksami [Oskar Wilde]; Która droga człowiek chce pójść, ta należy go prowadzić [Talmud]; Droga w góre jest droga $w$ dót [Heraklit z Efezu]; Dla cnoty żadna droga nie jest bezdrożem [Owidiusz]; Droga do bogactwa prowadzi przez prace i oszczędność [Benjamin Franklin]; Długa jest droga wiodaca od rozumu do serca [Gottfried Wilhelm Leibniz]; W każdym małżeństwie to nie droga jest trudna, lecz trudności sa droga [Soren Kierkegaard]; Nie pytaj Boga o drogę do nieba, bo wskaże ci najtrudniejsza [Stanisław Jerzy Lec]; Człowiek wolny idzie do nieba taka droga, jaka mu się podoba [Wolter]; Idź swoja droga, a ludzie niech mówia, co chca [Dante Alighieri].

Każdy może zinterpretować wymienione przysłowia według własnego uznania, co oznacza, że peryferyjne komponenty semantyczne moga się zmieniać.

W języku ukraińskim w paremiach ${ }^{11}$ [Пцав'юк 1998] odnoszących się do tematu towarzyszenia komuś w drodze odnajdujemy opozycje добрий (товариш, співрозмовник, супутник) - поганий: тоді дорога спішна, коли розмова потішна; Краше погана дорога, нік поганий супутник; В дорозі і батько брат; Товариш мовний в дорозі стоїть за віз смарований; Одинокому дорога дуже довга; podkreśla się, że do drogi trzeba być przygotowanym: Хліб у дорозі не затяжить; Коли хліб на возі, то нема біди в дорозі; Погана мотузка і та в дорозі знадобиться; В дорозі і голка важить; w podróży koniecznie trzeba znać trasę, żeby nie zbłądzić: Коли не знаєш дороги, не виїжджкай з дому; Не збочуй з дороги, бо відпокутують ноги; Хто дороги не питає, той ногами набивае; Не бійся дороги, аби коні були здорові; Велика дорога починається з першого кроку. Utrwaliło się już stereotypowe wyobrażenie starej i nowej drogi (cmapa i нова дорога) czy prostej - krzywej drogi (проста - крива дорога): Старою дорогою легко ходити; Новою дорогою іди, але i cmapy не забувай; Проста дорога найліпша; Простою дорогою найборше зайдеш; Для простої дороги кривого гостиния не минай. $Z$ droga w obu kulturach kojarza się dobre i złe omeny [Жайвоpонок 2018, 209]: czarny kot przebiegł drogę - niepowodzenie (zarówno w języku polskim, jak i ukraińskim); ktoś przez przypadek przeszedł droge $z$ pełnymi wiadrami - powodzenie, a $z$ pustymi - niepowodzenie; kiedy ktoś wyrusza w drogę, to przed wyjściem $z$ domu musi na chwilę usiąść. Droga gładka symbolizuje lekkość, drogę bez przeszkód: I нa гладкій дорозі мене лихо спіткало; I на гладкій дорозі чоловік не раз ногу зломить; W drogę zgodnie $z$ tradycja ukraińską zawsze wyprowadzała żona albo dziewczyna, stąd przysłowie $B$ дорозі пам'ятай о небозі

11 To przysłowie i następne pochodzą ze zbiorów przysłów: Украӥнсъкi прислів'я, приказки, фразеологізми, http://igra1.com/ua/pryslivya-pro/prysl ivya-pro-dorohu.htm; Приказкu i npuслів'я, http://teka.ks.ua/post/narodni/ prysliv-ia-ta-prykazky-pro-dorohu/; В. Пцав'юк, 1998, Приповідки або українсъко-народня філософрія, Едмонтон, Канада. 
albo Ой ти козаче, ти, хрешатий барвіночку, хто ж тобі постеле y дорозі та постілочку. Fatalne w kulturze ludowej jest pol. skrzyżowanie dróg, ukr. nерехрестя albo pol. rozdroże, ukr. роздоріжжя.

Podobnie jak w języku polskim, ukraińskie paremie reprezentuja 'nieprzewidywalność wydarzeń podczas podróży': В дорозі всъого трапиться; Хто часто в дорозі, був під возом і на возі; Коли на те піде, то й серед битого шляху поламаєшся; Дома рука й нога спить, а в дорозі й голова не дрімає; Коли стелиться доріжка, козакові не до ліжкка; Дорога і вночі не сnить. O drodze myśli się dużo i dużo się mówi - Дорога на кіниі язика; Домашня думка в дорогу не годиться, czasem o drogę trzeba zapytać - ukr. Язик до Києва доведе i pol. Јęzyk $i$ do Rzymu doprowadzi.

Definicyjne cechy drogi (zarówno w języku polskim, jak i ukraińskim) jako nazwy określonego fragmentu rzeczywistości znajdujemy w połączeniu $z$ innymi słowami, np. z przymiotnikami: droga leśna, polna, wiejska; droga asfaltowa, brukowana, kamienista; dobra, zła droga; droga szeroka, waska, mało uczęszczana, błotnista, wyboista; droga kręta, prosta, równa; droga główna, obwodowa, wylotowa, publiczna [Dubisz (red.) 2003, 700]; ukr. дорога довга, коротка, вузька, широка, пряма, рівна, крива, далека, безлюдна, протоптана, бита, знана, певна, нова, незвідана, життєва [Москальчук 2015: 5]. Konotacyjne cechy odnajdujemy w kontekście: Droga ciężka, koło południa upał; Droga prześliczna. Wysokie topole po bokach, smukke, kolumnowe; ${ }^{12}$ Droga wydaje sie prosta, widać ja jak na dłoni; 3 uieï мumi dopoza cmara важиa і небезпечніша. Підйом дедалі крутішав, прірви ставали загрозливо глибокими, а стежини дедалі вужиими, ${ }^{13}$ Був серед них запорожеиь один. Повів їх на Січ. Довгою $і$ незвичайно важкою була та дорога; Дорога пряма і одноманітна.

Natomiast w połaczeniach $z$ czasownikami wyraz droga tworzy metafory: droga wije się, zakręca, rozwidla się. Zarówno w języku polskim, jak i ukraińskim droga ulega personifikacji, mówi się, że droga idzie, pnie się pod góre, stromo w góre, biegnie, wchodzi, wychodzi, prowadzi, wiedzie. Takie połączenia czasownikowe są liczne w obu językach: Dalej droga biegnie do Ornety. Tam, gdzie zaczynała sie przesieka i droga wchodziła w las, brzegi strumyka spinat mostek $z$ grubych bali; Dokad ta droga prowadzi? Bita droga wita się między rzadkim lasem, koślawe brzózki rosły obok kepp rozczapierzonych sosen; Znowu jechalismy lasem, potem droga skręciła $i$ weszła nagle $w$ smuge nieruchomego, zimnego światła; Droga ostro zawinęta w prawo; Droga wychodzi z lasu; Za Pogorzeła droga początkowo opadata, a później wznosi się na wysokość $250 \mathrm{~m}$ n.p.m.

12 Ten i następne przykłady cytowane za: Narodowy Korpus Języka Polskiego, http:/ /www.nkjp.uni.lodz.pl/

${ }_{13}$ Ten i następne przykłady cytowane za: Корпус українсъкої мови, http:/ / korpus.org.ua/ 
W języku ukraińskim czasowniki dają bardziej urozmaicone połączenia $z$ wyrazem droga: Дорога метнулася від річки, аби згодом знову повернутися до неї, здійняла куряву; Дорога звузилась $\boldsymbol{i}$ занурилась у маленький гай; Дорога пролягала через рисові і джутові поля; Поки дорога йтиме через наші землі, тобі нема чого боятися; Раптом на ию пустелю полив дош, і дорога стелилася перед нами мокра і зовсім безлюдна; Я бачив засніжене поле, десь під тим снігом загубилася дорога; Ще за якусь чверть години дорога загубилася вже в лісі; З горба дорога в'еться серпентиною вниз; Дорога то пidiŭмалася, то опускалася; Важка дорога зблизила їх, здружила. W tekstach poetyckich droga krzyczy, zbliża, martwi sie, zamiera, mami: Тільки завмирає, журиться дорога / Може ти не прийдеш, гарна й кароока; Тільки манить ввечері дорога / У казково загадковий світ; Все було, дорога закричала, / Блиснули байдужі ліхтарі, / Ти пішла від мене до причалу / I згоріла в полум'ї зорі; Нелегка тобі лягла дорога / В світ иирокий, з отчого порога; Дорога була покраяна колесами возів.

Istotna rolę w tworzeniu obrazu metaforycznego odgrywaja porównaпіа: Через село гадюкою петляла дорога, вона вела кудись далекодалеко на схід; Дорога звивалася зміею поміж будинками; Дорога білою стрілою гнулася від небокраю до небокраю; Дорога вигиналася, наче велетенський лук; Переді мною дорога простяглася полотном. Porównywanie drogi $z$ wężem (ukr. змія, гадюка) pomaga wyobrazić sobie kształt drogi, ilustruje fakt, że to jest droga $z$ zakrętami; droga jak strzała jest długa i prosta, jak łuk ma kształt wygięty, może być równa jak płótno. Konotacyjne cechy podkreślają czasowniki: nemляла, звивалася, вигиналася, простягалася. Tutaj również moga występować asocjacje: czasownik torować, ukr. mopyвamu łączy się wyłącznie ze słowami droga / дорога (nymb), podobnie czasownikowe połączenie dopoza звивалася як wуwołuje skojarzenie jedynie $z$ wyrazami змія, гадюка 'wąż, gad'. Mamy tutaj do czynienia $z$ podwójnym podkreśleniem cech 'droga z zakrętami', 'prosta droga', 'wygięta droga' - wyrażone rzeczownikami i czasownikami.

Droga jest konceptualizowana jako nieoczekiwane przeszkody, trudności, ujemny fizyczny wpływ na człowieka, np. w języku polskim: Odpoczywam po drodze i myśle o was; Uwięzła gdzieś $w$ drodze na małej stacji; Deszcz spłukał nas w tej drodze nieźle; Była uciążliwa droga; w języku ukraińskim: Злива зійшла на дрібний дошик, дорога - на суиільне жовте місиво; Дорога туди ой яка важка взимку.

W obu językach obserwujemy sporo użyć potocznych: droga tam i z powrotem / дорога myди i назад; $w$ pół drogi do Zakopanego / на півдорозі до...; godzina $w$ tę $i w$ te stronę / година туди i назад.

Językowy obraz życiowej drogi przedstawia się jako szereg różnych odcinków życia zorganizowanych kontrastowo (podniesienie i upadek, radość i smutek, sukcesy i porażki, początek i koniec), które realizuja się przez określenia droga trudna, ukr. складна, важка, непроста, 
устелена тернами, правдива: Wtedy niewiele о sobie wiedziałem, choć przeczuwałam, że czeka mnie droga, trudna, ale jedyna, przeznaczona właśnie dla mnie; ...Zyskasz zewnętrzne porozumienie i spokój, gdyż najpewniej zorientujesz się, która droga życiowa jest dla ciebie wtaściwa, tatwiejsza, z która sobie poradzisz; Dalsza droga życia rysowała mi sie już wyraźnie, prosta, nietatwa, ale bez zasadzek; ukr. Чомусь дорога июбові в усіх світах завжди устелена гострими тернами випробувань, розчарувань, зрад $і$ зваб; Загине рідня - обірветься $і$ наша дорога; Але духовна дорога була правдива.

$\mathrm{W}$ obu badanych językach obraz drogi wyobrażany jest także jako kierunek zmierzania do celu, do poszukiwania realizacji celu, dążenie do czego: Droga do tego celu prowadzi tylko $w$ jednym kierunku - $w$ kierunku zmiany samego siebie; Wiele było dróg danych człowiekowi, by szedt, $i$ wiele manowców. Weronika wiedziała, że jedna tylko droga prowadzi do celu...; Nauczyłem sie tak wiele, że aż trudno mi opowiedzieć. Droga mojej nauki była wyboista; Jest to jeszcze jedno otwarte okno lub droga w kierunku jakiejś rzeczywistości, która istnieje i która $w$ ten sposób można sobie i innym przybliżyć. Powinniśmy z tej możliwości skorzystać; Moja droga do wiary była zupelnie inna. Spotykałem sie $z$ wiara ludzi najprostszych, $z$ religia wspólnot. Droge do transcendencji widziałem jako droge do wspólnoty. Analogicznie w języku ukraińskim: Переді мною ніби намічалася дорога в літературу. Але ж-у чужу. Та й стежечка була вузенька; Була ще одна евентуальна дорога: вступити до академії мистеитв $і$ затриматись на малярському шляху. Але ж була й малісінька шуілина до світської високої школи; Дорога до справжнъого мистеитва лежить через довгі роки наполегливої праиі; Важкка і крута їхня до порятунку дорога; Але шо ж ви зможете мені допомогти, коли до здійсненя моӥх мрій дорога закрита.

Czasem, aby zrozumieć koncept, przywołujemy szerszy kontekst, np. Cóż więcej potrzeba człowiekowi, któremu pozostawała $w$ życiu do odbycia tylko jedna droga - ze szkoty na arene, a stamtad przeważnie $\boldsymbol{w}$ śmierć. Wolność gladiator zdobywa rzadko, nim wysłużył wyzwolenie, zdobywał wolność wieczysta - na cmentarzu gladiatorów.

Droga to pojęcie odnoszące się również do czasu: Дорога тільжи в один кінець займе зо два місяиі; Дорога до дачного містечка не забрала багато часу; Droga do pracy zajmowała mu piętnaście minut.

$* * *$

Przedstawiony szkic stanowi tylko próbę rekonstrukcji językowego obrazu drogi w języku polskim i ukraińskim. Znaczenia drogi w obu językach w definicjach słownikowych pokrywają się w całości. Jednak w języku polskim na pierwszy plan wysuwa się znaczenie 'pas ziemi łączący 
poszczególne miejscowości', w języku ukraińskim - 'pas ziemi, po którym jeździ się i chodzi', czyli przeznaczenie drogi, jej funkcja. Analiza materiału językowego (zwiąków frazeologicznych, przysłów i sentencji) pokazała bogactwo treści, jakie niesie ze sobą leksem droga w języku polskim i ukraińskim. Spośród przeanalizowanych ok. 50 polskich i 50 ukraińskich połączeń frazeologicznych większość ma swoje polskie i ukraińskie odpowiedniki: pol. droga krzyżowa-ukr. хресна дорога; pol. być na dobrej drodze - ukr. виходитu на вiрну дорогу; pol. zejść, zboczyć z prostej drogi - ukr. зійти з рівної дороги. W szczególnych wypadkach różnice są nieznaczne: pol. iść kręta droga, chodzić krętymi drogami odpowiadaja ukr. cmaвamu (cmynamu) / cmamu (cmynumu) на слизький шлях (слизьку дорогу); збиватися з дороги; збочувати з дороги (зі шляху); збитися з дороги на манівиі; збиватися з путі сzу tед̇ pol. pójść $w$ droge wieczności, zakończyć drogę - ukr. [бутu] на Божій (останній) дорозі, збиратися в дорогу, уже на дорозі, іти в дорогу додому; пора збиратися в дорогу; уже в дорозі; в дорозі до Бога. W obu językach w połaczeniach frazeologicznych można odnaleźć komponenty semantyczne: 'droga życiowa' - od początku i do końca życia, 'postępowanie człowieka' ( $z$ ocena pozytywna lub negatywna), 'osiagnięcie celu', 'poszukiwanie sposobu rozwiązania problemu'. Nieliczne frazeologizmy nie maja odpowiedników w języku polskim, np. cmoвnoвиŭ (верстовий) шлях, стовпова (верстова) дорога - 'główny kierunek ruchu albo w rozwoju czegoś'; шлях заказаний - 'ktoś pozbawiony możliwości, dostępu do czegoś'; myдu ŭ дорогa / скатертю дорога, albo odwrotnie, polskie frazeologizmy nie maja odpowiedników ukraińskich, np. droga cnoty, nie ma złej drogi zemście na wrogi. Wspólne doświadczenia człowieka, wspólne schematy wyobrażeniowe zwiąane $z$ droga, podróża, poruszaniem się w przestrzeni, celem podróży, nieprzewidywalnością wydarzeń podczas podróży odnajdujemy również w przysłowiach i sentencjach (poddano analizie 35 ukraińskich i 30 polskich przysłów i sentencji).

Można wywnioskować, że zarówno w kulturze polskiej, jak i w ukraińskiej ukształtował się podobny językowy obraz drogi. Cechy definicyjne i konotacyjne maja wspólne sposoby ich wyrażania, widoczne sa jedynie różnice w częstości użycia leksemu droga w konkretnych kontekstach (poddano analizie około 500 użyć, przywołano około 100 polskich i ukraińskich). W tym zakresie można prowadzić badania porównawcze tekstów poetyckich, artystycznych, politycznych i innych.

\section{Bibliografia}

M. Bańko, 2009, Stownik peryfraz, czyli wyrazów omownych, Warszawa.

A. Bańkowski, 2000, Etymologiczny stownik języka polskiego, t. 1-2, Warszawa.

J. Bartmiński, 2012, Językowe podstawy obrazu świata, Lublin. 
T. Budrewicz, 2002, Językowy obraz drogi w poezji Konopnickiej, https://rep. up.krakow.pl/xmlui/bitstream/handle/11716/1736/16-Jezykowy-obrazdrogi-Budrewicz.pdf?sequence=1\&isAllowed=y [dostęp: 25.02.2021].

A. Dąbrówka, E. Geller, 2001, Słownik antonimów, Warszawa.

S. Dubisz (red. nauk.), 2003, Uniwersalny słownik języka polskiego, t. I-IV, Warszawa.

D. Filar, P. Łozowski, 2018, Gramatykalizacja i leksylalizacja pojęć a językowy obraz świata. Szkic o ekwiwalencji kognitywnej, „Etnolingwistyka. Problemy Języka i Kultury" nr 30, file:/ / C:/Users/Polonistyka\%20PNU/Downloads/Gramatykalizacja_i_leksykalizacja_pojec_a_jezykowy.pdf [dostęp: 25.03.2021].

R. Grzegorczykowa, 2004, Pojęcie językowego obrazu świata [w:] J. Bartmiński (red.), Jezykowy obraz świata, Lublin, s. 39-46.

K. Kłosińska, 2004, Słownik przysłów, czyli przysłownik, Warszawa.

W. Kopaliński, 2003, Słownik mitów i tradycji kultury, Warszawa.

I. Kurcz, A. Lewicki, J. Sambor i in., 1990, Słownik frekwencyjny polszczyzny współczesnej, Kraków.

A. Latusek, P. Pilarski, 2012, Wielki słownik wyrazów bliskoznacznych, red. M. Tomczyk, Kraków.

A. Lewicki, 1998, Próba profilowania pojęcia DROGA na podstawie idiomatyzmów języka polskiego [w:] J. Bartmiński, R. Tokarski (red.), Profilowanie $w$ języku i tekście, Lublin, http:/ /www.isybislaw.ispan.waw.pl/ShowDocument. do?documentId=98430\&webeId=webepartners\&utm_source=webepartners\&utm_medium=other\&utm_campaign=webepartners [dostęp: 25.02.2021].

D. Ludwiczak, A. Piskadłowa, E. Tarka-Huczek, 2004, Słownik wyrazów bliskoznacznych, Warszawa.

J. Maćkiewicz, 2004, Wyspa - jezykowy obraz wycinka rzeczywistości [w:] J. Bartmiński (red.), Językowy obraz świata, Lublin, s. 193-206.

Narodowy Korpus Języka Polskiego, http://www.nkjp.uni.lodz.pl/ [dostęp: 13.03.2021].

A. Pajdzińska, 2018, Kategorie gramatyczne a językowy obraz świata, „Etnolingwistyka. Problemy Języka i Kultury" nr 30, s. 41-53.

Przysłowia i cytaty na każda okazję, złote myśli, sentencje i wyrażenia, https:/ / cytaty24.pl/cytaty/Droga/Aforyzmy,Sentencje/k/19?pagec=1 [dostęp: 12.03.2021].

S. Skorupka, 1999, Słownik frazeologiczny języka polskiego, t. 1-2, Warszawa.

E. Skorupska-Raczyńska, 2013, Kreacja ojca $w$ powieściach nadniemeńskich Elizy Orzeszkowej (studium językowo-stylistyczne), Gorzów Wielkopolski.

K. Smyk, 2014, Nazwy drogi we współczesnej polszczyźnie. Analiza leksykalnosemantyczna, http://cejsh.icm.edu.pl/cejsh/element/bwmeta1.element.ojs-issn-2083-1765-year-2014-issue-9-article-5138 [dostęp: 26.02.2021].

Słownik etymologiczny języka polskiego, https://sciaga.pl/slowniki-tematyczne/5392/droga/ [dostęp: 09.03.2021].

K. Termińska, J. Szarlej, 2015, Powinowactwa obrazów drogi w hebrajszczyźnie biblijnej i współczesnym języku polskim, https://www.researchgate.net/publication/339500004_Powinowactwa_obrazow_DROGI_w_hebrajszczyznie_ biblijnej_i_wspolczesnym_jezyku_polskim [dostęp: 02.03.2021].

R. Tokarski, 1999, Językowy obraz świata w metaforach potocznych [w:] J. Bartmiński (red.), Językowy obraz świata, Lublin, s. 65-81. 
S. Urbańczyk, 1992, Encyklopedia języka polskiego, Wrocław-Warszawa-Kraków.

M. Wilczewska, 2008, Kognitywna metafora drogi w wybranych tekstach muzycznych zespołu „Armia”, „Prace językoznawcze” z. X, https://bazhum.muzhp. $\mathrm{pl}$ /media/files/Prace_Jezykoznawcze/Prace_Jezykoznawcze-r2008-t10/ Prace_Jezykoznawcze-r2008-t10-s2 19-232/Prace_Jezykoznawcze-r2008t10-s219-232.pdf [dostęp: 10.03.2021].

А. Бурячок, 1999, Словник синонімів українсъкої мови, Київ.

В. Винник (ред.), 2003, Словник фразеологізмів українсъкої мови, Київ.

I. Голубовська, 2004, Етнічні особливості мовних картин світу, Київ.

В. Жайворонок, 2007, Українсъка етнолінгвістика, Київ.

В. Жайворонок, 2018, Антологія знаків українсъкої культури, Київ.

Корпус української мови, http://korpus.org.ua/ [dostęp: 15.03.2021].

Т. Мизин, 2020, Аексеми rоаd/дорога в англійсъкій та украӥнсъкій мовних картинах світу, „Науковий вісник Херсонського державного університету, серія: Германістика та міжкультурна комунікація", випуск 1. http://tsj.journal.kspu.edu/index.php/tsj/issue/view/19/32 [dostęp: 04.03.2021].

А. Москальчук, 2015, Кониепт "дорога" у структурі художнъої картини світу В. Шевчука: традииї та індивідуально-авторські складники, „Синопсис: текст, контекст, медіа” nr 3(11), https://synopsis.kubg.edu.ua/ index.php/synopsis/article/view/162/153 [dostęp: 11.03.2021].

В. Пцав'юк, 1998, Приповідки або украӥнсько-народня філософрія, Едмонтон, Канада.

Приказки і прислів'я, http:/ / teka.ks.ua/post/narodni/prysliv-ia-ta-prykazkypro-dorohu/ [dostęp: 02.03.2021].

В.М. Русанівський (ред.), 2013, Словник українсъкої мови, т. 4, Київ.

Словник українсъкої мови online, т. 1-11, https://sum20ua.com/?page=995\& wordid=30301[dostęp: 11.03.2021].

Українські прислів'я, приказки, фразеологізми, http://igra1.com/ua/ pryslivya-pro/pryslivya-pro-dorohu.htm [dostęp: 12.03.2021].

Фразеологія сучасної украӥнсъкої мови, http://schoollib.com.ua/ukr_ lang/1/54.html [dostęp: 12.03.2021].

М.Г. Шиеньова, 2013, Мовний образ дороги в поезії В. Голобородъка, https:/ / naub.oa.edu.ua/2013/movnyj-obraz-dorohy-v-poeziji-v-holoborodka/ [dostęp: 18.03.2021].

\section{Językowy obraz drogi w języku polskim i ukrainskim}

\section{Streszczenie}

W przedstawionym artykule poddano analizie językowy obraz drogi w języku polskim i ukraińskim w perspektywie porównawczej. Opisano znaczenia leksemu droga przedstawione w słownikach, synonimy, metafory i metonimie, przysłowia ilustrujące różne znaczenia drogi. W rekonstrukcji językowego obrazu drogi uwzględniono analizę łączliwości leksykalnej wyrazu droga, warstwę 
konotacyjna, czyli zjawisko „rozszerzania się semantyki” na podstawie analizy korpusów tekstowych. Artykuł wpisuje się w nurt badań językoznawczych ukierunkowanych etnolingwistycznie, wykorzystujac aparat badawczy strukturalizmu i kognitywizmu.

Słowa klucze: językowy obraz świata - droga - leksem - semantyka kontekst.

\section{The linguistic view of the road in Polish and Ukrainian}

\section{Summary}

The presented paper analyses the linguistic view of the road in Polish and Ukrainian from a comparative perspective. It describes the meanings presented in dictionaries, synonyms, metaphors and metonyms, proverbs reflecting the concept of the road. The reconstruction of the linguistic view of the road includes the analysis of the lexical connectivity of the word road, the connotation layer and the phenomenon of "semantics expansion" based on an analysis of text corpora. The paper is part of the stream of ethnolinguistically oriented linguistic research, while using the research apparatus of structuralism and cognitivism.

Keywords: linguistic worldview - road - lexeme - semantics - context.

Adj. Monika Czarnecka 